\author{
Ewelina Kwiatkowska \\ dr inż. \\ Politechnika Wrocławska \\ Katedra Mostów i Kolei \\ kwiatkowskae@interia.pl
}

DOI: $10.35117 /$ A_ENG_17_10_02

\title{
Research quality railroad crossings with under sleepers pad
}

\begin{abstract}
Research quality railroad crossings with under sleeper pad. The quality of the railway track is infl uenced by a number of factors, such as durability, reliability, swelling and cost. The article made use of impact assessment under sleepers pad (USP) on the quality of rail track. The author has presented laboratory research, computer research and dynamic study of turnouts with USP. The impact of the USP on the quality of turnouts was assessed. Research results have shown an increase in the quality of turnouts with USP.
\end{abstract}

Keywords: Railway turnout; Vibration isolation; Track quality

\section{Introduction}

The railway surface is designed to carry out railway traffic with the assurance of safety, continuous and regular train traffic. The continuity of the traffic requires the exploitation of the surface, covering its use and renewal. It must be assumed that the railway lines are in the state of use or renewal, in special cases the line may be simultaneously in the state of use or renewal. The railway surface can be located in one of three states: full, limited operational suitability and unserviceable operation. The use may take place at full operational capacity, i.e. the state of normal maintenance of the railway surface or in a limited state if the trains move and take place at speeds lower than the maximum provided for the given line. The railway track renewal conditions occur during planned technological closures, unplanned closures, and technological closures. The quality of the $(\mathrm{J})$ railway surface is determined by a set of characteristics such as: reliability $(\mathrm{N})$ and service life $(\mathrm{T})$, maintenance and repair vulnerability $(\mathrm{P})$ and economic characteristics (E) of the pavement, described by (1) where, a1 -4 is the weighting factor, including the characteristics of the reference surface.

$\mathrm{J}=a_{1} \frac{N_{w}}{N}+a_{2} \frac{T}{T_{w}}+a_{3} \frac{P}{P_{w}}+a_{4} \frac{E_{w}}{E}$

$\mathrm{N}=\beta \frac{n}{l q}$

,where $\mathrm{n}$ the number of unplanned and emergency track closures per year on the length of the line $l, q$ is the intensity of transport, $\beta$ is the rate coefficient $\beta=1,4-0.004 V_{\text {max }}$.

The operational durability of the surface is the load $Q$ at which the total number of single rails exchanges over $1 \mathrm{~km}$ does not exceed $\mathrm{k}$ meters. Maintenance and repair susceptibility is the length of the track on which current repairs are carried out within 1 hour of closing [1].

\section{Durability and reliability of turnouts}

Damage to the railway surface at the turnout is more complex than damage on the track sections and proceeds much more quickly. The railway crossing is an element of the railway line, whose durability and reliability ensures the safety of railway traffic. 
The faster process of turnout degradation is caused by greater dynamic impacts of rail vehicles in places of discontinuity of rafter and cross-over towers and hardness of structural steel of crossover and cross-link. In the switch section, the most dangerous damage is the nonadherence of the needle to the resistor, chipping on the running surface of the needle and the resistor. In the frog section, defects and damage to the turnout causing the necessity of limited exploitation are: crushing the beak of the frog, cracking of the frog, flow in the grooves of the wing rails. Sleepers in the frog part are subjected to uneven dynamic load, causing transverse cracks in prestressed concrete sleepers.

\section{Technical requirements for turnouts}

According to the list of the President of the Office of Rail Transportation on the issues of the relevant national technical specifications and standardization documents, the use of which makes it possible to meet the essential requirements regarding the interoperability of the rail system of 19 January 2017 for the subsystem infrastructure indicated a closed list of components requiring technical solutions for which it is necessary certificates of placing in service for a railway construction type intended for railway traffic. Among the components requiring a clearance certificate for explantation are listed for the classic surface: sleepers, turnout and rail fastening system [4].

In accordance with the Technical Specifications for Interoperability of the infrastructure [4], the technical characteristics of turnouts must be in accordance with the operational values: maximum value of the track gauge is $1380 \mathrm{~mm}$, the minimum value of the width in common frogs is $1392 \mathrm{~mm}$ [5].

In accordance with the detailed technical conditions for the modernization or construction of railway lines up to a speed $\mathrm{Vmax} \leq 200 \mathrm{~km} / \mathrm{h}$ (for conventional rolling stock) / $250 \mathrm{~km} / \mathrm{h}$ (for rolling stock with a tilting box) TOM I - turnouts, it is recommended to use concrete sleepers. On railway lines subjected to modernization or construction, it is permissible to use the construction variant of the turnout provided for the higher-type line, provided that their use does not lead to a significant increase in investment costs. However, in the case of the qualifications of the entire station to the lower level type as part of the modernization or construction to a given type, a higher standard should be used in turnouts. And if you qualify the entire station to a lower one by two or more rungs, turnouts should be used in the standard at a higher level, ensuring an extended operational capacity [6].

According to the Visual Inspection Instruction, Technical Testing and Maintenance of the Id-4 PKP PLK turnouts from 2015, technical tests of turnouts for a maximum speed above $120 \mathrm{~km} / \mathrm{h}$ are performed every 3 months and for speeds above $160 \mathrm{~km} / \mathrm{h}$ every 2 months. The tests are aimed at checking the durability of the turnout and maintaining full operational capacity. The permissible vertical wear of the spire, resistors, wing rails, crossbar, connecting rails is $8 \mathrm{~mm}$ for speeds above $120 \mathrm{~km} / \mathrm{h}$. The permissible lateral wear qualifying needles, fastening systems, and crossings to be replaced is $10 \mathrm{~mm}$, and the deviation of the wear surface from the vertical axis of the rail is $30^{\circ}$ for movements above $120 \mathrm{~km} / \mathrm{h}$, with an allowable lateral steering wear of $4 \mathrm{~mm}$. During everyday inspections and periodic tests of turnouts, the operational capability is assessed and as a result of maintenance and repair work the full operational quality of the turnout is maintained [2].

\section{Tests of durability of turnouts with pads in turnout sleepers}

In order to extend the durability and reliability of turnouts, pads (PPP) are used in prestressed concrete turnout sleepers. The use of elastic vibroinsulation materials in turnout sleepers 
reduces the threshold effect caused by the change of track surface stiffness before turnout and on the turnout.

As a result of the use of PPP, there is a reduction in dynamic interactions in the crossing zone in the turnout sleepers, because the contact area of the turnout with the breakstone is increased. Increasing the contact surface of the sleepers with breakstone occurs as a result of the bedding of the ballast grains into a springy PPP layer. The contact area of the turnout with breakstone is 5\%, with the use of PPP the contact surface of the sleeper with smashing is $20 \%$.

Fig. 1 shows the contact surfaces of the smashing with the sleeper from the PPP production by Getzner and without vibroinsulation. The contact surface was tested on the black painted bottom surface of the primer without PPP and with PPP and on the white painted crushed stone, the sleeper was placed in a ballast trunk with crushed stone and subjected to a load $112 \mathrm{kN}$ [3].

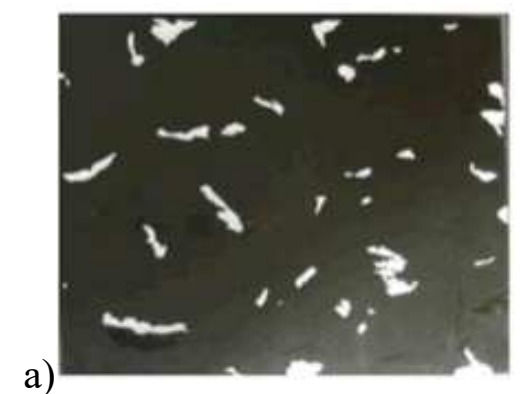

1. The contact surface of the sleeper with breakstone, and sleeper without a pad under the contact is $5 \%$, b- a sleeper with a pad under the contact is $20 \%$

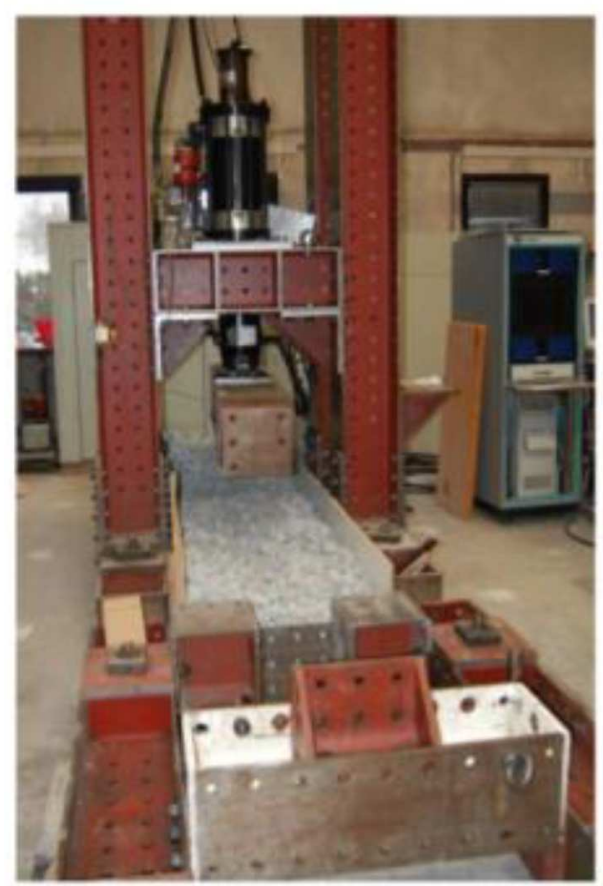

2. Test stand of the contact surface of the sleeper with the breakstone grains 
As a result of the use of pads in the sleepers, there is an increase in resistance to transverse shift. Increasing the resistance to the transverse shift in the turnout is particularly important at the crossing of turnout. When changing direction to the diverging track, dynamic forces are greatest. Fig. 3 presents a test stand for measuring the resistance to transverse travel carried out with pads in turnout and without PPP [3].

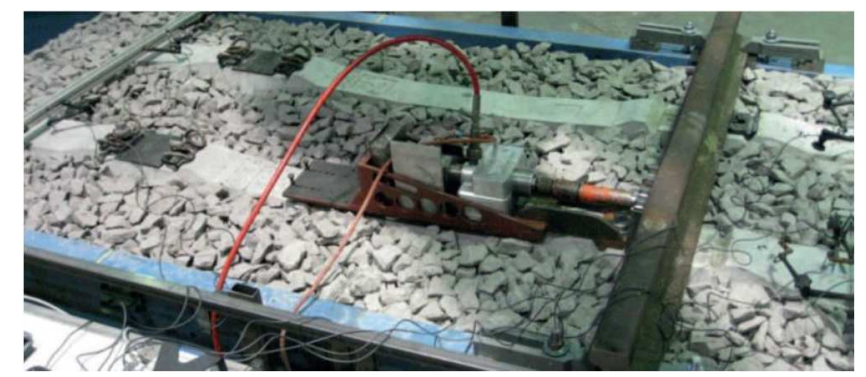

3. Test stand of transverse shift in turnouts with PPP in a ballast trunk

The study was carried out on two types of sleepers, the first type are prestressed concrete sleepers without vibration isolation (without PPP), the second type are foundations with antivibration insulation type G04 V05 (with PPP). The comparative study was aimed at determining the magnitude of the average size and force forcing the shift, the test was carried out for two tested sleepers at $2 \mathrm{~mm}$ travel, $97 \mathrm{kN}$ horizontal force at $4 \mathrm{~Hz}$, undercut pressure of $8 \mathrm{kN}$, the results are summarized in table 1 [3].

Tab. 1. The results of the resistance tests on the transverse shift with PPP and without PPP

\begin{tabular}{|l|l|}
\hline Types of pads & $\begin{array}{l}\text { Pad shift indicator of 2 mm, average } \\
\text { value }[\mathrm{kN}]\end{array}$ \\
\hline $\begin{array}{l}\text { Pre-stressed concrete B70 without } \\
\text { PPP }\end{array}$ & 6,4 \\
\hline $\begin{array}{l}\text { Pre-stressed concrete B70 with } \\
\text { PPP } \\
\text { type G04 V05 }\end{array}$ & 8,3 \\
\hline
\end{tabular}

Increasing the contact area of the turnout with breakstone as a result of sinking grains with the elastic layers of the pad causes an increase in resistance to transverse shift. The use of PPP in the approach reduces vertical and horizontal deformations in the turnout caused by the operational movement, maintaining full operational ability resulting from the increase in the durability of the structure.

During the use of the turnout, uneven wear of the parts of the turnout causes the necessity to conduct maintenance works limiting the operational capability. The amount of dynamic loads in the crosspoint zone is the greatest, resulting from the loss of contact between the wheel of the set during crossing the cross and asymmetric loading of the turnout sleepers. Uneven wear of the turnout eliminates the use of PPP in turnouts with different static and dynamic stiffness. Fig. 4 presents the results of numerical simulations showing the increase of vertical 
deformations on the turnout length without PPP black, PPP with one stiffness, blue color and a switch with PPP with different static stiffness and dynamic PPP material on the turnout length [3].

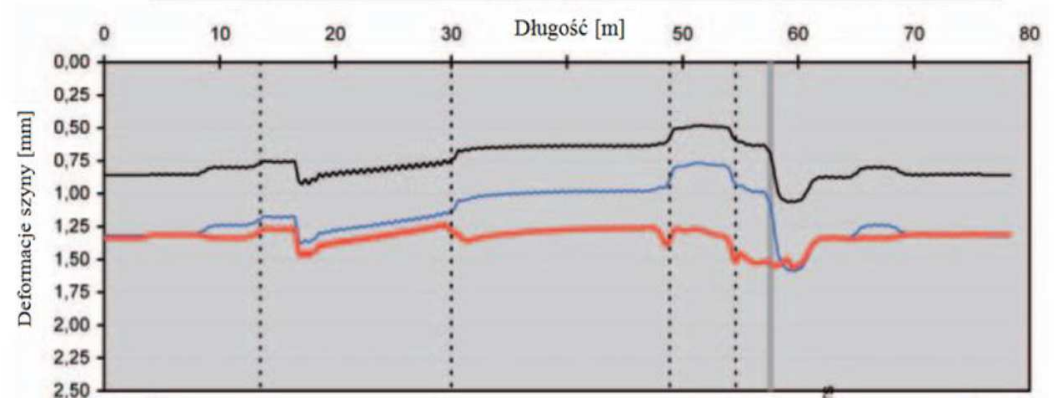

4. Results of vertical deformation tests at the turnout distance, black line crossover without PPP, blue line crossover with one PPP type, red line crossover with PPP with different PPP stiffness.

The results of the tests (fig. 4) showed that the use of PPP with different stiffness limits the increase of vertical deformations in the cross-section of crossroads. Reduction in the growth of stepped vertical deformations in the crossings reduces the dynamic effects caused by the passing train, improving the quality of exploitation by extending the durability.

\section{Study of turnouts from PPP on the PKP PLK network}

In order to assess the impact of the use of PPP in turnouts on the operated PKP PLK network, the author started in 2016 the program for testing the operation of turnouts with pads at the Wrocław University of Technology in the Cathedral of Bridges and Railway.

The research program is aimed at assessing the impact of the use of PPP in the turnout on the quality of the operated railway surface, the characteristics of reliability and operational durability, maintenance and repair susceptibility and economic characteristics.

The test bed was located on the modernized in 2014 station Siedlce in the province Mazowieckie on two turnouts produced by Track Tec KolTram. First turnout type Rzl 1: 12500-60E1 with PPP, second turnout type Rzp 1: 12-500-60E1 without PPP with crossings with insert manganese type.

Turnout studies have been divided into three parts. The first stage involved testing with a laser scanner of the Scorpion Graw type of a 3D profile of a crossbar (Figure 5) and a needle (Fig.6). The scanner scan was carried out at the Siedlce station on the turnout with the PPP and without PPP in February 2016 and at the factory in Zawadzkie on new spires and crossings (Fig.7) in April 2016. The research was aimed at assessing the wear of the profile of the frog and spire during operation.

In the second part, research was carried out on the propagation of vibrations caused by the passage of the train at a speed of $70 \mathrm{~km} / \mathrm{h}$ in the Siedlce station at the turnout with PPP and without PPP. The tests were aimed at assessing the level of vibrations caused by passing the train on the turnout and substructure construction as a result of using pads in turnout sleepers. The study was conducted in August 2016.

The third part of the research includes diagnostic measurements made in four measurement series every 3 months from January 2016 on the turnout with PPP and without 
PPP at the Siedlce station, measurements have been made in accordance with the instructions in the Id4 and are not presented in this publication.

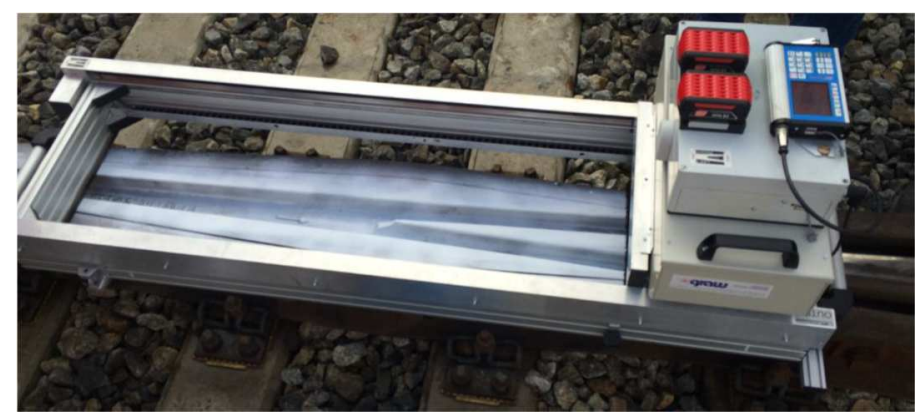

5. 3D Scorpion scanner in a turnout with PPP at Siedlce station, February 2016

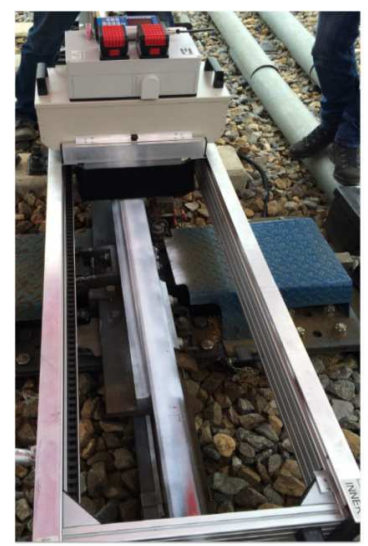

6. Spire 3D Scorpion scanner measurement in a turnout with PPP at Siedlce Station, February 2016

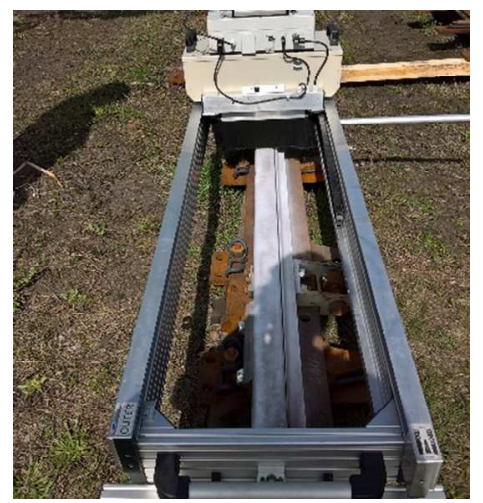

7. Measurement of a new spire with a Scorpion scanner in Track Tec Koltram Zawadzkie, April 2016

The results of the measurement of the spire and frog profile are shown in Fig. 8. The comparison of the measurement results for the turnout with PPP and without PPP and the new elements showed wear on the frog beak in the turnout without PPP of $0.52 \mathrm{~mm}$, and in the turnout with PPP turnover $0.35 \mathrm{~mm}$ in comparison with a new frog. When measuring the spire 
in a turnout without PPP, it was $0.32 \mathrm{~mm}$, and in the turnout with PPP it was $0.28 \mathrm{~mm}$ compared to the new spire. An example image from the scanner is shown in Fig. 8.

a)

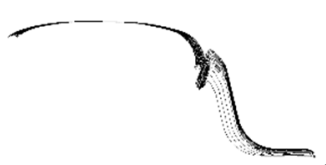

8. Image from the Scorpio type 3D scanner, a - spire, b-frog

Dynamic impact study was carried out using Photon Brüel \& Kjaer photographic equipment. The test was carried out at the Siedlce station when the train had the speed of $70 \mathrm{~km} / \mathrm{h}$ in the main direction at the turnout with PPP and without PPP. The measurement sensors are laid on the rail, the sleeper in the switch zone and in the diverging sphere at a distance of $5 \mathrm{~m}$ from the track axis (Fig.9).
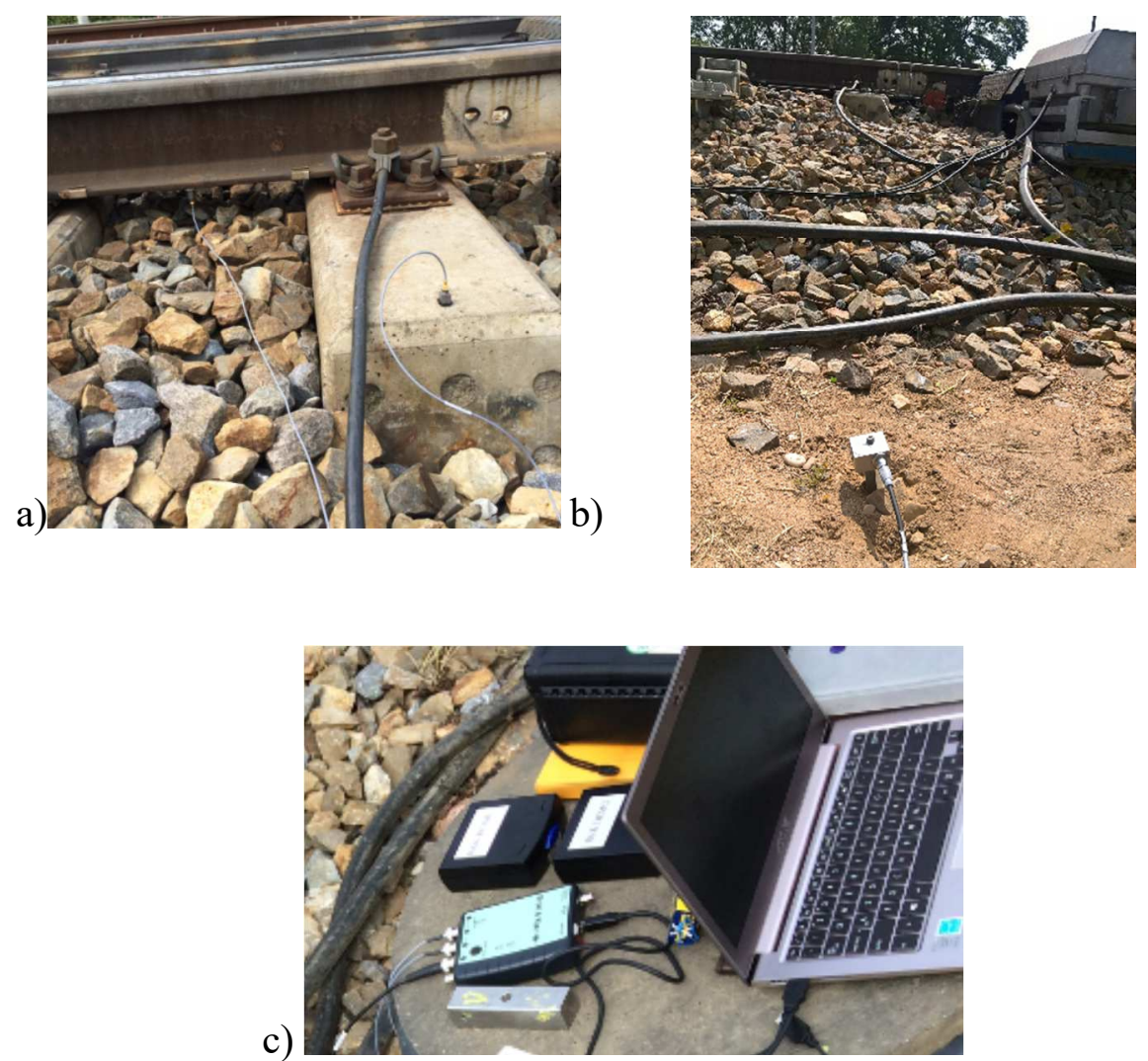

9. Measuring apparatus and location of measurement sensors in the turnout, a- sensors on the rail and sleepers, b- sensor in the substructure, c-measuring apparatus, Siedlce August 2016

The conducted measurements were subjected to frequency analysis in the comparative range for the PPP turnout and without PPP. As a result of the application of pads in turnout sleepers, the vibration reduction in the rail by $20 \%$, in the turnout by $30 \%$, and in the substructure by 
$40 \%$ in the frequency range from 5 to $40 \mathrm{~Hz}$ occurred compared to the turnout without PPP. In the frequency range from 40 to $240 \mathrm{~Hz}$ there was a reduction of vibrations in the rail by $25 \%$, in the turnout sleepers by $35 \%$, and in the substructure by $60 \%$ in the turnout with pads in comparison to the turnout without PPP.

\section{Source materials}

[1] Bałuch H. Trwałość i niezawodności eksploatacyjna nawierzchni kolejowej WKit, Warszawa 1980 r.

[2] Instrukcja o oględzinach, badaniach technicznych i utrzymaniu rozjazdów Id-4 PKP PLK z 2015

[3] Kwiatkowska E.: Wpływ wibroizolacji podkładów strunobetonowych na pracę podtorza kolejowego, Raport serii PRE nr 8 /2015, Politechnika Wrocławska

[4] Lista Prezesa Urzędu Transportu Kolejowego w sprawach właściwych krajowych specyfikacji technicznych i dokumentów normalizacyjnych, których zastosowanie umożliwia spełnienia zasadniczych wymagań dotyczących interoperacyjności systemu kolei z dnia 19 stycznia 2017 r.

[5] Rozporządzenie Komisji Europejskiej (UE) nr 1299/2014 z dnia 18 listopada 2014 r. dotyczące technicznych specyfikacji interoperacyjności podsystemu „Infrastruktura” systemu kolei w Unii Europejskiej

[6] Standardy techniczne PKP PLK szczegółowe warunki techniczne dla modernizacji lub budowy linii kolejowych do prędkości $V \max \leq 200 \mathrm{~km} / \mathrm{h}$ (dla taboru konwencjonalnego) $/ 250 \mathrm{~km} / \mathrm{h}$ (dla taboru z wychylnym pudłem) TOM I - rozjazdy 